\title{
Human Resource Development and Management of Tertiary Education for global Competitiveness in Nigeria
}

\author{
Abdullahi Nimota Jibola Kadir*
}

\begin{abstract}
This study investigated the extent to which boosting of staff morale, staff empowerment and team building served as a strategy for ensuring effective management of tertiary education for global competitiveness in Nigeria. Quantitative research design was used for the study. Seven public tertiary education institutions in Kwara State were purposely selected for the study. The view of 330 lecturers and 21 school managers were sampled through stratified and simple random sampling techniques. The population of this study comprised of 3,600 academic staff in public tertiary education institutions in Kwara State. Sample of 330 lecturers and 21 school mangers were selected with the use of Research Advisor (2006) table to determine the sample size of a known population. A self-designed questionnaire titled "Human Resource Development for Global Competitiveness Questionnaire" (HRDGCQ) was used to collect information for the study. The data collected were analyzed using $t$-test statistical analysis. All hypotheses were tested at 0.05 level of significance. The result revealed that there was no significant difference between the boosting of staff morale, staff empowerment, teem building and management of tertiary education for global competitiveness. It was recommended that effort should be made by government to continue boosting staff moral by providing conducive environment, proper support of staff, as well as participation of staff in organizational decision making. Staff empowerment should also be part of government priorities in the management of tertiary education. Furthermore, government and school administrators should encourage team building among lecturers so as to enhance effective management of tertiary education for global competitiveness in Nigeria.
\end{abstract}

Keywords: Human resource, development, tertiary education, global competitiveness.

This Article can be cited as:

Kadir A N J., (2020). Human Resource Development and Management of Tertiary Education for global Competitiveness in Nigeria, Journal of Arts and Social Sciences. VII (1), 75-88.

\footnotetext{
* Correspondence concerning this article should be addressed to Abdullahi, Nimota Jibola Kadir, PhD Schholar, Department of Educational Management, Faculty of Education. University of Ilorin, Nigeria. abdullahi.njk@unilorin.edu.ng , neematabdullahi@gmail.com , neematkadir@yahoo.co.uk.
} 


\section{Introduction}

The readiness of any country to exploit the inherent benefit of education is largely dependent on the quality and type of development provided for human resources. Human resources development generally is the process that ensures persistent increase in knowledge skills, and competence required for effective performance of tasks and duties towards the achievement of global competitiveness. The development of any country is to a large extent dependent on the trained and competent human resources available for effective production and management of her resources. The day-to day running of a tertiary institution as an organization is also dependent on trained human resources. Human resources are people which exploits natural resources and builds socio-political structure which determine the degree of benefit that can be drawn from the global system towards effective global competitiveness.

Management has been described as a process involving responsibility and effective planning and maximum utilization of available resources towards the fulfillment of stated goals and objectives (Abdullahi, 2018). This implies the process of planning, organizing, staffing and controlling of both human and material resources in an organization in order to realize the predetermined goals.

Tertiary education according, to the National Policy on Education (FRN, 2013) is the terminal stage of formal education. It comes after secondary education and its existence is seen in such institutions as Universities, Polytechnics/ Monotechnic and Colleges of Education. The activities of tertiary education include, teaching, research and community development. The objectives of tertiary education include: the contribution to national development through high level relevant manpower training; the promotion of national and international understanding and interaction; the offer of high quality career counselling and lifelong learning programmes that enhance students with the knowledge and skills for self-reliance and the world of work; the promotion the intellectual capacity of individuals to understand and appreciate their local and external environment; the development and encouragement scholarship and community service; the reduction of skill shortages through the production of skilled manpower relevant to the needs of the labour market.

Several studies have been carried out in the area of human resources and competitiveness. Ugbam and Obi-Anike (2016) carried out their study global competitiveness, human capital development and Nigeria vision 2020. Jovanka (2014) investigated higher education and training as crucial pillars in creating the competitiveness of nation. Nathaniel (2010) conducted enhancing global competitiveness of the Nigeria economy: Implication for multi-lateral trade. Afza and Nazir (2007) investigated economic competitiveness and human resource development: A FDI perspective. Debrah and Ofori (2006) carried out human resource development of professionals in an emerging economy: the case of Tanzanian construction industry. Khan (2005) conducted human resource development, competitiveness and globalization. There are several areas on human resource development and global competitiveness that are yet to be covered by these scholars. These areas include human resource development and management of tertiary education in Kwara State, Nigeria. This study on human resources development and management of tertiary education for global competitiveness in Nigeria therefore endeavor to fill some parts of these gap yet to be covered. To address the research gap of this study, this paper explicitly attempts to:

a) determine the relationship between boosting of staff morale and management of tertiary education for global competitiveness.

b) examine the relationship between staff empowerment and management of tertiary education for global competitiveness

c) identify the relationship between team building and management of tertiary education for global competitiveness. 


\section{Research Hypotheses}

The following hypotheses were formulated and tested:

$\mathrm{H}_{01} \quad$ There is no significant difference between the mean scores of school managers and lecturers on boosting of staff morale and management of tertiary education for global competitiveness in Kwara State.

$\mathrm{Ho}_{2}$ There is no significant difference between the mean scores of school managers and lecturers on staff empowerment and management of tertiary education for global competitiveness in Kwara State.

$\mathrm{H}_{03} \quad$ There is no significant relationship between mean scores of school managers and lecturers on team building and management of tertiary education for global competitiveness in Kwara State.

\section{Literature review}

\section{Human Resource Development}

Human resource development is concerned with the development of human capacities which are potentially available for use toward the betterment of a country. This means that human resources development is an investment in people in order to make them grow and contribute to the development of their environment. It is concerned with the need to make people productive and contribute to organization's vision and achievement of objective (Okeke, 2010). Human resource development refers to the process of continuously injecting new ideas, skills, values, attitude and knowledge into individuals as may be required for the development of nation (Ignatius, 2013). Human resource development in this study refers to the personal development of staff which could have impact on staff morale, empowerment as well as team building among staff in order achieve stated organizational goals.

Morale generally refers to the emotional reaction of a person to his job in terms of courage, zeal, discipline enthusiasm and willingness to endure hardship for goal attainment. There is positive relationship between low morale and a high rate of absenteeism, laziness and indolence in an organization. Loafing and constant bickering are signs of dissatisfaction with the job and indication of low morale. On the other hand, promptness, cooperation, enthusiasm and readiness to contribute to the development of organization are indications of high self-esteem (Okeke, 2010). This means, the way people feel about their job makes a significant difference in productivity. Effective management of staff morale in terms of providing and furnishing staff with efficient and sufficient working tools and creation of conducive atmosphere in which they can perform their duties. There are several ways of boosting staff morale in tertiary education which can contribute to effective global competitiveness. These include recommending effective staff for promotion, assigning post of responsibility, facilitating professional and academic growth or advancement so as to ensure global good competitiveness.

Staff empowerment is a way of creating a certain degree of autonomy of performing specific tasks. Empowerment enhances employee morale, increases their sense of responsibility and quality of work performed. Also, it is one of the most effective tools for increasing staff job performance and efficient use of individual capacity towards the realization of organizational and individual's goals (Azarinia, 2008). The process of empowerment improves effectiveness, creativity and individual commitment to work (Wang, 2012). Human resources development in this study refers to the process of boosting staff morale, empowerment as well as team building among staff.

Team building generally implies various activities undertaken to encourage the team member and improve the overall performance of the work group. Team building is the process of helping a team to become more effective in carrying out its tasks and satisfying the need of the team members (Orok, 2014). Fajana (2002) proclaims that team building is an integration of human resource and input to work in 
harmony in order to achieve organizational goals and objectives. Dianna (2006) asserts that team building is a form of collective work that might involve each member to in contributing their own quota towards the development of organization.

\section{Managing Tertiary Education for Global Competitiveness}

Management generally is the ability to cope with complexity towards devising structures and systems in an organization for the effective utilization of available resources and for the purpose of realizing the predetermined objectives. Management is the application of rational and systematic analysis of available resources and maximum utilization of these resource towards the achievement of the stated goals and objective (Abdullahi, 2018).

Tertiary education aims at providing efficiency by getting the work force to gain qualifications which serve as an important factor to obtain competitiveness (Sathye, 2004). Tertiary education is of crucial importance in the development of production systems, implementation of new technologies and training a specialized workforce which will be capable of adapting to the changing needs of system toward achieving global competitiveness.

The concept of global competitiveness emerged to enhance and increase world-wide integration of market for goods, services, capital and mutual benefits. The World Economic Forum defines global competitiveness as "the ability of a country to achieve sustained high rates of growth in gross domestic product (GDP) per capital”. In assessing a country's global competitiveness, it is easy to measure the degree to which it is coping positively in the global game-play in terms of quality education, specialization and infrastructure. Also, measuring global competitiveness in enhancing a diagnostic analysis of an existing relationship and encourages a recommendation of policies to achieve better performances of individual and country.

\section{Theoretical framework}

The theoretical framework of this study is develop based on two factor theory by Herzberg (1967). According to this theory, there are some factors that result in satisfaction while there are other job factors that prevent dissatisfaction. Herzberg classifies these job factors into two categories: Hygiene and Motivator factors. Hygiene factors are those job factors which are essential for existence of motivation in an organization. These do not lead to positive satisfaction in the long-term. But if these factors are absent in an organization, then they lead to dissatisfaction. Hygiene factors such as policy and administration, supervision, working condition, relationship with worker, relationship with supervision which when adequate, pacify the employees and do not make worker dissatisfied. These factors are extrinsic to the worker. The hygiene factors symbolized the physiological needs which the individuals want and expect to be fulfilled. The motivator factors motivate the employees for a superior performance. These factors are called satisfiers. Employees find these factors intrinsically rewarding. The motivators symbolize the psychological needs that are perceived as an additional benefit. Motivator factors include recognition, personal growth, advancement achievement, opportunity, work itself and individual responsibility.

This theory can be functional in the school system such that the government and school authority can make use of motivational factors by boosting staff morale in terms of praising and the recognition of staff for their accomplishment, giving staff a sense of achievement, growth and advancement opportunities (employee empowerment) in an organisation to motivate the staff to perform well in order to achieve organisational effectiveness towards global competitiveness. Also, managers can minimize control by encourage team building and retain accountability to make work meaningful, interesting and challenging for the staff towards global competitiveness. Furthermore, regular payment of reasonable salary can be of paramount and it must be equal and competitive to those in the same domain. Educational policies must be clear and fair to all stakeholders' concerns, teaching equipment must be updated and well -maintained. The 
lecturer status in the society should be improved and retained as well as provide job security to lecturers so as to provide good product in term self-confidence and self- reliance graduates for effective global competitiveness.

\section{Methodology}

\section{Research Design}

This study used the quantitative research design in order to sample the views of lecturers and school managers (HODs, Deans and Directors) in University of Ilorin. This design enables researcher to determine relationship among different variables (Meyers, 2013). Therefore, the quantitative research design will enable the researcher to determine the kind of relationship exists among boosting of staff morale, staff empowerment, team building and global competitiveness (McNabb, 2013).

\section{Population and Sampling}

The population of this study consists of lecturers and school managers in 7 public tertiary education institutions in Kwara state, Nigeria. The population in this study comprises of about 3,600 staff. Out of this, the researcher makes use a total of 351 participants based on recommendation of Research Advisor (2006) table of determining sample size of a known population. Purposive random sampling technique was used to select 330 lecturers and 21 school managers. Random sampling technique was used in selecting participants for this study, this was to ensure that every member of the population has equal chance and right of being selected (Creswell, 2012). In this regard, all categories of lecturers and school managers in tertiary education institutions are represented in this study.

\section{Research Instrument}

A self-designed questionnaire titled: "Human Resource Development for Global Competitiveness Questionnaire" (HRDGCQ). With 20 items spread across 4 sections (A, B, C. \& D) was used to collect data. Section A of the questionnaire centres on demographic information of participants. Section B with 7 items centers in boosting of staff morale. Section C with 7 items centres on Staff empowerment while section D with 6 items centres on team building respectively. This questionnaire was designed on 4 Likert scale of Strongly Agree $(\mathrm{SA})=4$, Agree $(\mathrm{A}=3)$, Disagree $(\mathrm{D})=2$ and Strongly Disagree $(\mathrm{SD})=1$. The criterion means of 2.5 and above was used for agreed and below 2.5 was used for disagree. the 4-point Likert scale answer format was easier and faster to complete than 5 to 7 -point scales answer format (Brown, 2000; Allen \& Christopher, 2007).

\section{Validity and Reliability}

The questionnaire was validated by three different experts in the field of educational management and three experts in measurement and evaluation including 2 professors, 2 associate professors and 2 senior lecturers. Each expert gave his or her opinion and suggestions for the questionnaire 's improvement. The questionnaire was corrected according to the expert's recommendation. Furthermore, 20 corrected copies were administered to lecturers and school managers who are part of the sampled to examine their understanding of the items wording, instructions questions and scales of the questions in order to detect if there are any challenges that may arise in filling the questionnaire.

Test of reliability instrument was to measure the repeatability and consistency of an outcome and how much we can depend on the outcome (Mayer, 2013). Therefore, the researcher examined the reliability of all the 20 items in the questionnaire using in this study using Cronbach's Alpha as presented in Table 1. 
Table 1. Reliability Test for HRDGCQ

\begin{tabular}{lllll}
\hline Variable & Sub-variable & N & $\begin{array}{l}\text { Cronbach's } \\
\text { Alpha }\end{array}$ & Decision \\
\hline $\begin{array}{l}\text { Human Resources } \\
\text { Development }\end{array}$ & Boosting of staff morale & 7 & 0.88 & All items are acceptable and reliable \\
& Staff empowerment & 7 & 0.82 & All items are acceptable and reliable \\
& Team building & 6 & 0.84 & All items are acceptable and reliable \\
$\begin{array}{l}\text { Management } \\
\text { Tertiary Education }\end{array}$ & Planning & 5 & 0.80 & All items are acceptable and reliable \\
& Motivation & 5 & 0.84 & All items are acceptable and reliable \\
& coordination & 5 & 0.82 & All items are acceptable and reliable \\
\hline
\end{tabular}

Table 1 shows the value of the Cronbach's Alpha for 7 items under boosting of staff morale is 0.88 . Also, the table reveals that 7 items of staff empowerment have a Cronbach's Alpha of 0.82 and team building has 6 items with a Cronbach's Alpha of 0.84 . Based on management of tertiary education indices, the Cronbach's alpha value for sub-indices are 0.80 for planning, 0.84 for motivation and 0.82 for coordination. According to (Pallant 2011; Ary, Jacobs\& Sorensen, 2010) values above 7 are considered acceptable or reliable and values above .8 are preferable. Therefore, the Cronbach's Alpha value for all the items in each variable shows very good internal consistency reliability for scale and all the 35 items in the questionnaire are found to be good and reliable.

\section{Administration of the Instrument and data Collection}

The participants were contacted in their respective offices to discuss the basis of the study before the distribution of the questionnaire. The researcher with the help of six research assistants personally distributed the instrument to the lecturers and school managers of the sample public tertiary education institutions in Kwara State. The participants were contacted in their various offices prior to the distribution of the questionnaire. The researcher and research assistants solicited their support to participate in the study. Thereafter, participants were contacted in their various offices and institutions. The researcher and the research assistants waited for the lectures and school managers to answer the questions and collected the questionnaire immediately when they had responded to the items in the instruments. This method facilitated hundred percent retrieval.

\section{Data Analysis}

The data collected for the study analyzed using descriptive statistics like mean and standard deviation to determine the objectives of the study. Inferential statistics such as t-test for the hypotheses. The $\mathrm{t}$-critical value was compared to the significance level of (0.5) to determine the rejection or acceptance of the hypotheses.

\section{Demography Data of Participants}

This section presents a comprehensive demographic data of participants made from the information collected in this study using simple percentage. 
Table 2. Demographic Profile of the Participants

\begin{tabular}{l|l|l|l|l}
\hline & & $\mathrm{N}=699$ & Percentage (\%) & \\
\hline Sex & Male & 196 & $56 \%$ & \\
& Female & 155 & $44 \%$ & \\
\hline & & 351 & $100 \%$ & \\
\hline Average age & $21-30$ & 04 & $1 \%$ & \\
& $31-40$ & 122 & $35 \%$ & \\
& $41-50$ & 150 & $43 \%$ & \\
& 51 above & 75 & $21 \%$ & \\
\hline & & 351 & $100 \%$ & \\
\hline Qualification & B.Ed & 04 & $1 \%$ & \\
& M.Ed. & 90 & $26 \%$ & \\
& PhD & 257 & $73 \%$ & \\
& & & & \\
\hline Years of experience & $1-10$ years & 63 & $100 \%$ & \\
& $10-20$ years & 213 & $61 \%$ & \\
& 21 years above & 75 & $21 \%$ & \\
\hline & & 351 & $100 \%$ & \\
\hline
\end{tabular}

Table 2 shows the demographic data of the participants that are involved in this study. Majority 196 (56\%) participants are male while $155(44 \%)$ are female. In terms of the average age, majority 150 (43\%) participants are between ages 41-50 year while $4(1 \%)$ are between ages 21-30. Based on qualification, majority 257 (73\%) of the participants are PhD holder while $4(1 \%)$ are B.Ed holder. Majority $231(61 \%)$ have $10-20$ years' experience while $75(21 \%)$ have 21 years above in the sample institution.

\section{Findings} objectives.

This section discusses the result of the findings. The findings were organized based on research

\section{Provision of Adequate Funding}

This section presents a detailed result of the analysis made from the data collected from 330 lecturers and 21 school managers in public tertiary education institutions in Kwara State. Detailed result is presented in the sub-heading:

Table 3. Boosting Staff Morale

\begin{tabular}{|c|c|c|c|c|c|c|}
\hline \multirow[t]{2}{*}{$\mathbf{S} / \mathbf{N}$} & \multirow[t]{2}{*}{ Boosting Staff Morale } & \multicolumn{2}{|c|}{$\begin{array}{l}\text { School Managers } \\
\text { Responses }\end{array}$} & \multicolumn{2}{|c|}{$\begin{array}{l}\text { Lecturers } \\
\text { Responses }\end{array}$} & \multirow[t]{2}{*}{ Decisior } \\
\hline & & Mean & SD & Mean & SD & \\
\hline 1 & $\begin{array}{l}\text { Provision of conducive environment and } \\
\text { appropriate resources boost staff morale. }\end{array}$ & 3.05 & .973 & 2.94 & .974 & Agreed \\
\hline 2 & $\begin{array}{l}\text { Effective support of staff boosts their morale } \\
\text { towards global competitiveness. }\end{array}$ & 3.10 & .831 & 2.93 & .978 & Agreed \\
\hline
\end{tabular}




$\begin{array}{llllllll}3 & \begin{array}{l}\text { Effective participation of staff in decision-making } \\ \text { enhance global competitiveness. }\end{array} & 3.29 & .845 & 2.93 & .991 & \text { Agreed } \\ \mathbf{4} & \begin{array}{l}\text { Promotion of staff regularly boost their morale } \\ \text { toward global competitiveness. }\end{array} & 3.19 & .814 & 2.70 & 1.024 & \text { Agreed } \\ \mathbf{5} & \begin{array}{l}\text { Provision of job security in an organization bring } \\ \text { about global competitiveness. }\end{array} & 3.05 & .831 & 2.79 & .976 & \text { Agreed } \\ \mathbf{6} & \begin{array}{l}\text { Regular payment of staff salary improves their } \\ \text { morale. }\end{array} & 3.10 & .845 & 2.93 & .992 & \text { Agreed } \\ \begin{array}{l}\text { Provision of advancement opportunity for staff } \\ \text { bring about global competitiveness. }\end{array} & 3.29 & .740 & 2.94 & 1.033 & \text { Agreed } \\ \text { Overall Mean } & 3.15 & 0.841 & 2.88 & 0.995 & \end{array}$

(Mean $\geq 2.5$ Agree, Mean $<2.5$ Disagree)

As shows in Table 3, the overall mean for school managers and lecturers' perception on boosting of staff morale is $3.15(\mathrm{SD}=0.841)$ and $2.88(\mathrm{SD}=0.995)$ respectively. This could be interpreted that participants agreed that boosting of staff morale bring about effective management of tertiary education for global competitiveness. The mean for each items was above the criteria mean of 2.5 and so was accepted as follows: Provision of conducive environment and appropriate resources boost staff morale $(M=3.05$, $S D=.973)$ and $(M=2.94, S D=.974)$, effective support of staff boost their morale towards global competitiveness $(M=3.10, S D=.831)$ and $(M=2.93, S D=.978)$, effective participation of staff in decisionmaking enhance global competitiveness $(M=3.29, S D=.845)$ and $(\mathrm{M}=2.93, \mathrm{SD}=.991)$, promotion of staff regularly boost their morale toward global competitiveness $(M=3.19, S D=.814)$ and $(M=2.70, S D$ $=1.024)$, provision of job security in an organization bring about global competitiveness $(M=3.05, S D=$ $.831)$ and $(M=2.79, S D=.976)$, regular payment of staff salary improve their morale $(M=3.10, S D=$ $.845)$ and $(M=2.93, S D=.992)$, provision of advancement opportunity for staff bring about global competitiveness $(M=3.29, S D=.740)$ and $(M=2.94, S D=1.033)$. Therefore, the participant agreed as the extent to which boosting of staff morale bring about effective management of tertiary education for global competitiveness.

\section{Staff Empowerment}

This is about the relationship between staff empowerment and global competitiveness.

Table 4.Staff Empowerment and Global Competitiveness as Responded by Lecturers and School Managers

\begin{tabular}{|c|c|c|c|c|c|c|}
\hline \multirow[t]{2}{*}{$\mathbf{S} / \mathbf{N}$} & \multirow[t]{2}{*}{ Staff Empowerment } & \multicolumn{2}{|c|}{$\begin{array}{l}\text { School Managers } \\
\text { Responses }\end{array}$} & \multicolumn{2}{|c|}{$\begin{array}{l}\text { Lecturers } \\
\text { Responses }\end{array}$} & \multirow[t]{2}{*}{ Decision } \\
\hline & & Mean & SD & Mean & SD & \\
\hline 8 & Empowerment bring about great job satisfaction & 2.86 & 1.062 & 2.89 & 0.963 & Agreed \\
\hline 9 & $\begin{array}{l}\text { Greater autonomy stimulates creativity and } \\
\text { generate better ideas. }\end{array}$ & 3.29 & 0.784 & 2.94 & 0.907 & Agreed \\
\hline 10 & $\begin{array}{l}\text { Empowerment help workers to improve their sense } \\
\text { of self confidence. }\end{array}$ & 2.52 & 0.873 & 2.95 & 0.969 & Agreed \\
\hline 11 & $\begin{array}{l}\text { Empowerment help to honourably adapt to change } \\
\text { to meet global competitiveness. }\end{array}$ & 3.29 & 0.784 & 2.93 & 0.913 & Agreed \\
\hline 12 & $\begin{array}{l}\text { Empowerment align goals of staff with those of } \\
\text { organization. }\end{array}$ & 2.25 & 0.873 & 2.96 & 0.970 & Agreed \\
\hline
\end{tabular}


13

14
Empowerment allow independent decision- $2.71 \quad 1.056$ making.
$3.24 \quad 0.831$

The overall efficiency of an organisation can be multiplied due to empowerment. $\begin{array}{llll}2.88 & 0.895 & 2.91 & 0.964\end{array}$
$2.87 \quad 1.018 \quad$ Agreed

$2.82 \quad 1.009 \quad$ Agree

\section{Overall Mean}

(Mean > 2.5 Agree, Mean <2.5 Disagree). Researcher field work

Table 4 showed the mean and standard deviation of items as follows: Empowerment brings about great job satisfaction $(M=2.86, S D=1.062)$ and $(M=2.89, S D=.963)$, greater autonomy stimulates creativity and generate better ideas $(M=3.29, S D=.784)$ and $(M=2.94, S D=.907)$, empowerment help workers to improve their sense of self confidence $(M=2.52, S D=.873)$ and $(\mathrm{M}=2.95, \mathrm{SD}=.969)$, empowerment help to honourably adapt to change to meet global competitiveness $(M=3.29, S D=.784)$, empowerment align goals of staff with those of organization $(M=2.25, S D=.873)$ and $(M=2.96, S D=$ $.970)$, empowerment allow independent decision-making $(M=2.71, S D=1.056)$ and $(M=2.87, S D=$ 1.018), the overall efficiency of an organisation can be multiplied due to empowerment $(M=3.24, S D .831)$ and $(M=2.82, S D=1.009)$ which means that the mean score was above the criteria mean of 2.5 . The items therefore show that staff empowerment enhances effective management of tertiary education for global competitiveness.

\section{Team Building}

Descriptive analysis of data collected from participant on team building.

Table 5. Team Building

\begin{tabular}{|c|c|c|c|c|c|c|}
\hline \multirow[t]{2}{*}{$\mathbf{S} / \mathbf{N}$} & \multirow[t]{2}{*}{ Team Building } & \multicolumn{2}{|c|}{$\begin{array}{l}\text { School Managers } \\
\text { Responses }\end{array}$} & \multicolumn{2}{|c|}{$\begin{array}{l}\text { Lectures } \\
\text { Responses }\end{array}$} & \multirow[t]{2}{*}{ Decision } \\
\hline & & Mean & SD & Mean & SD & \\
\hline 15 & $\begin{array}{l}\text { Team building encourage a positive view of } \\
\text { differences. }\end{array}$ & 2.86 & 1.062 & 2.92 & 0.964 & Agreed \\
\hline 16 & $\begin{array}{l}\text { People coming together building relationship that } \\
\text { result to effective morale and empowerment. }\end{array}$ & 3.29 & 0.784 & 2.97 & .0 .922 & Agreed \\
\hline 17 & Creates opportunities for networks and friendship. & 2.52 & 0.873 & 2.95 & 0.968 & Agreed \\
\hline 18 & $\begin{array}{l}\text { Team building help in coordinating staff roles and } \\
\text { functions to accomplish the common goals and } \\
\text { task. }\end{array}$ & 3.24 & 1.022 & 2.83 & 1.023 & Agreed \\
\hline 19 & $\begin{array}{l}\text { Team building encourage the group member to } \\
\text { share their learning as well as getting the new }\end{array}$ & 2.71 & 1.056 & 2.88 & 1.012 & Agreed \\
\hline \multirow[t]{3}{*}{20} & working experience. & 3.24 & 0.831 & 2.83 & 1.023 & Agreed \\
\hline & $\begin{array}{l}\text { Team building improve collegiality and support } \\
\text { the development of strong relationship in an } \\
\text { organization. }\end{array}$ & & & & & \\
\hline & Overall Mean & 2.98 & 0.906 & 2.89 & 0.985 & \\
\hline
\end{tabular}

(Mean $>2.5$ Agree, Mean $<2.5$ Disagree) Researcher field work 
Table 5 showed the overall mean for school managers and teacher responses on team building as $2.98(\mathrm{SD}=0.906)$ and $2.89(\mathrm{SD}=0.985)$ respectively. This could be interpreted that participants agreed that team building improve effective management of tertiary education for global competitiveness in Kwara State. The results of the analysis for each team building indicated that all the six items display a higher mean than criteria mean value of 2.5. The items are team building encourage a positive view of differences $(M=2.86, S D=1.062)$ and $(M=2.92, S D=0.964)$, People coming together building relationship that result to effective global competitiveness $(M=3.29, S D=0.784)$ and $(M=2.97, S D=0.922)$, Creates opportunities for networks and friendship $(M=2.52, S D=0.873)$ and $(\mathrm{M}=2.95, S D=0.968)$, team building help in coordinating staff roles and functions to accomplish the common goals and task $(M=3.24$, $S D=0.831)$ and $(M=2.83, S D=1.023)$, team building encourage the group member to share their learning as well as getting the new working experience $(M=2.71, S D=1.056)$ and $(M=2.88, S D=1.012)$, Team building improve collegiality and support the development of strong relationship in an organization $(M=$ $3.24, S D=0.831)$ and $(M=2.83, S D=1.023)$. Therefore, the participants accepted that team building enhance positive management of tertiary education for global competitiveness in Kwara State, Nigeria.

\section{Hypotheses Testing}

The t-test statistics analysis was used to test the set hypotheses as follow:

$\mathrm{Ho}_{1}$ : there is no significant difference between the mean scores of school managers and lecturers on boosting of staff morale and management of tertiary education for global competitiveness.

Table 6. Boosting of staff and Management of Tertiary Education for Global Competitiveness

\begin{tabular}{llllllll}
\hline Variable & $\mathbf{N}$ & $\overline{\boldsymbol{x}}$ & SD & df & Tcal & t-crit & Decision \\
\hline School managers & 21 & 3.15 & 0.841 & & & & \\
& & & & 349 & 1.21 & 1.96 & Accepted \\
Lecturers & 330 & 2.88 & 0.995 & & & & \\
\hline
\end{tabular}

Table 6 indicates the t-test analysis between the mean scores of school managers and lecturers' responses on boosting of staff morale management of tertiary education for global competitiveness. The tcalculated value of 1.21 is less than t-critical value of 1.96 . This means there is no significant difference between the responses of school managers and lecturers on boosting of staff morale management of tertiary education for global competitiveness (Skaik, 2015). Therefore, the null hypothesis which states that there is no significant difference between boosting of staff morale and management of tertiary education for global competitiveness is accepted.

Ho2: There is no significant difference between the mean scores of school managers and lecturers on staff empowerment and management of tertiary education for global competitiveness.

Table 7. Staff Empowerment and Management of Tertiary Education for Global Competitiveness.

\begin{tabular}{llllllll}
\hline Variable & $\mathbf{N}$ & $\overline{\boldsymbol{x}}$ & SD & df & Tcal & t-crit & Decision \\
\hline School Managers & 21 & 2.88 & 0.895 & & & & \\
& & & & 349 & 1.45 & 1.96 & Accepted \\
Lecturers & 330 & 2.91 & 0.964 & & & & \\
\hline
\end{tabular}


Table 7 indicates the t-test analysis between the mean scores of school managers' and lecturers' responses on staff empowerment and management of tertiary education for global competitiveness. The tcalculated value of 1.45 is less than t-critical value 1.96. This means there is no significant difference between responses of school managers and lecturers on staff empowerment and management of tertiary education for global competitiveness (Yim, Nahm, Ham \& Park, 2010). Therefore, the null hypothesis which states that there is no significant difference between staff empowerment and management of tertiary education for global competitiveness is accepted.

$\mathbf{H}_{\mathbf{0 3}}$ : There is no significant difference between the mean scores of school managers and lecturers on team building and management of tertiary education for global competitiveness.

Table 8. Team Building and Management of Tertiary Education for Global Competitiveness

\begin{tabular}{llllllll}
\hline Variable & $\mathbf{N}$ & $\overline{\boldsymbol{x}}$ & SD & df & Tcal & t-crit & Decision \\
\hline School managers & 21 & 2.98 & 0.906 & & & & \\
& 330 & 2.89 & 0.985 & & & & Accepted \\
Lecturers & & & & & & & \\
\hline
\end{tabular}

Table 8 indicates the t-test analysis between the mean scores of school managers and lecturers' responses on team building and management of tertiary education for global competitiveness. The tcalculated of I.75 is less than t-critical value of 1.96. This means there is no significant difference between the responses of school managers and lecturers on team building and management of tertiary education for global competitiveness (Skaik, 2015). Therefore, the hypothesis which states that there is no significant difference between team building and management of tertiary education for global competitiveness is accepted.

\section{Discussion}

The first finding in table three study shows that both lecturers and school managers were in agreement that boosting of staff morale in tertiary education institutions in Kwara State takes positive measure for effective management in order to ensure global competitiveness. Among the measures taken is to ensure provision of conducive environment, giving proper support to staff, promotion of staff regularly regular payment of staff salary, job security as well as provision of advancement opportunity for staff. From the first research hypothesis, it was found that there is no significant difference between boosting of staff morale and management of tertiary education for global competitiveness. This implies that effective management and provision of appropriate support for staff help in enhancing organizational global competitiveness. This is in line with Khan (2005) that human resource development is the essential precondition for improving employee, knowledge-based economy and creating country fully prepared for global competitiveness.

The second finding in table four shows that both the lecturers and school managers hold similar views on the measure used to empower staff in order to ensure global competitiveness in the management of tertiary education. In such that provision of empowerment bring about job satisfaction, stimulates creativity, improve staff sense of self-confidence, help staff to adapt to change, allow independent decision as well as improve overall efficiency of an organization. Result from hypothesis two shows that there is no significant difference between staff empowerment and management of tertiary education for global competitiveness. This finding corresponds with the position of Wang 
(2012) that empowerment improves individual commitment to job performance towards achieving organizational effectiveness.

The third finding in table 5 shows that both lecturers and school managers had similar opinions on the fact that team building bring about the effective management of tertiary education for global competitiveness. People coming together building a relationship that result in effective global competitiveness, encourage positive view of differences as well as creates opportunities for network and friendship. Result from hypothesis three revealed that there is no significant difference between team building and management of tertiary education for global competitiveness. This finding is agreed with Troen and Boles (2009) that team building share responsibility for the team success and for the success of all within the organization. Similarly, the study conformed to that of Debrah and Ofori (2006) who emphasis that the role of competent professional in term of team building, boost of staff morale and employee empowerment is a strategic importance to create global competitiveness.

\section{Implications and Recommendations}

Human resource development is an important factor in determining the success of tertiary education institutions. The findings of this study will help the government and stakeholders to recognize the fact that the world is changing, therefore, tertiary education institutions need to dance to the tune of nice image in the global community. Hence, lecturers and school managers need to be empowered so as to be able to compete with their colleagues globally. This finding will also help the lectures to improve on their academic activities so as to ensure effective global competitiveness. Researchers will also benefit from the outcome of this study as it will give appropriate direction for further research. The findings recommended that effort should be made by government to continue boosting staff morale by proving conducive working environment, proper support of staff, effective participation of staff in decision making regarding the appropriate steps to take in achieving the stated educational objectives, job security, regular payment of salary and provision of advancement opportunity for staff in order to achieve effective management of tertiary education for global competitiveness. Also, staff empowerment should be part of government priority in the management of tertiary education in that it helps workers to improve their sense of selfconfidence, adapt to change in an organization, bring about great job satisfaction towards achieving global competitiveness. In addition, government and school managers should encourage team building among lecturers in the management of tertiary education institutions for global competitiveness by building good relationship among staff, encourage a positive view of differences as well as creates opportunities for networks and friendship, dedicated funding for staff development that result in effective enhancement.

\section{Conclusion}

This paper focused on human resource development and management of tertiary education for global competitiveness in Nigeria. Based on the findings of this study it was concluded that boosting of staff morale, staff empowerment as well as team building in an institution of learning enhance effective management of such institution for achieving global competitiveness. Therefore, if all these measures are put in place by the government and school administrators, tertiary education institutions will achieve the predetermined objectives and thus respond positively to global competitiveness. Not only that, this will give all lecturers and school managers a sense of belonging irrespective of their place of origin. This in essence could help to enhance personal development and personal commitment to institutional development and growth to global competitiveness.

Further researcher can expand this study by using different location for the study, using some other variables to measure human resource development apart from variables used in this study. This study can also be carried out using different statistical analysis. 


\section{References}

Abdullahi, N. J. K. (2018). Corruption in education system and management of primary schools in Nigeria. Malaysia Online Journal of Educational Management (MOJEM), 6(1), 21-35

Afza, T. \& Nazir, M.S. (2007). Economic competitiveness and human resource development: An FDI perspective. Pakistan Economic Social Review, 167-180.

Allen, I. E. \& Christopher, A. S. (2007). Likert scales and data analyses. Quality Progress, 40(7),64-65.

Ary, D., Jacobs, L. C., \& Sorensen, C. (2010). Introduction to research in education ( $8^{\text {th }}$ ed.) California: Thomson Wadsworth.

Azarinia, M.A. (2008). Empowerment of key to increase productivity. Capital Newspaper, No. 810.

Brown, J. D, (2000). What issue affect Likert-scale questionnaire format. JALT Testing and Evaluation, 4, 27-30.

Creswell, J.W. (2012). Educational research: planning, conduction and evaluating quantitative and qualitative research ( $4^{\text {th }}$ ed.). Boston: Pearson.

Debrah, Y.A. \& Ofori, G. (2006). Human resource development of professionals in an emerging economy: The case of the Tanzanian construction industry. International Journal of Human Resources Management, 17(3), 440-463.

Dianna, D. (2006). Team: Teamwork and teambuilding, Parentice Hall, New York.

Fajana, S. (2002). Human resources management: An introductory. Published by Labofin and Company, Lagos.

Federal Republic of Nigeria. (FRN) (2013). National policy on education: Federal Ministry of Education. Yaba, Lagos - Nigeria.

Herzberg, F. (1967). Dual factor theory of job satisfaction; personal psychology. New York: Random House Inc.

Ignatius, A. (2013). Human resources development and the universal basic education in Nigeria. Mediterranean Journal of Social Sciences, 4(5), 19-26.

Jovanka, D.S. (2014). Higher education and training as a crucial pillar in creating the competitiveness of nation. Social and Behavioural Sciences, 241-246.

Khan, A.K. (2005). Human resource development, competitiveness and globalization: A South Asia perspective, SAARC Journal of Human Resource Development, 1(1), 5-54.

Mayer, A. (2013). Introduction to statistics and SPSS in psychology $\left(1^{\text {st }}\right.$ ed.) England: Pearson Education Limited.

McNabb, D. E. (2013). Research methods in public administration and non-profit management. Quantitative and qualitative approaches ( $3^{\text {rd }}$ edition). Armonk, NY: M.E. Sharpe. 
Nathaniel, A.A. (2010) enhancing global competitiveness of the Nigerian economy: Implication for multilateral trade. African Journal of Business Management, 4(17), 3571-3587.

Okeke, F.N. (2010). Staff personnel administration in Basic text on educational management (eds) I.L. anukam, P.O.O. Okunamiri \& R.N.O. Ogbonna. Imo State, EeHech Versatile Publishers.

Orok, B.A. (2014). Team building as an organization development strategy. Global Journal of Management and Research, 14(3), 81-84.

Pallant, J. (2011). A step by step guide to data analysis using SPPS: Survival manual. (4 ${ }^{\text {th }}$ ed.). Australia: Allen and Unwin.

Research Advisor (2006). Sample size table. http://WWW.reseach-advisor.com

Troen, V. \& Boles, K. (2009). The power of teacher teams. Cambridge, Massachusetts: Harvard Education Press.

Sathye, M. (2004). Leadership in higher education: A qualitative study. Journal of Qualitative Social Research, 15(3), 26-35.

Skaik, Y. (2015). The bread and butter of statistical analysis "t-test": Uses and misuses. Pakistan Journal of Medical Sciences, 31(16), 1558-1559.

Ugbam, O.C. \& Obi-Anike, H.O. (2016). Global competitiveness, human capital development and Nigeria vision 2020. European Journal of Business and Social Sciences, 5(2), 106-116.

Wang, J. (2012). The influences of psychological empowerment on work attitude and behaviour in Chinese organisation, Journal of business management, 6(30), 8938-8947.

Yim, K. H., Nahm, F. S, Han, K. A., Park, S. Y. (2010). Analysis of statistical methods and errors in the articles. Korean Journal of Pain, 23, 35-41. 